\title{
Erratum to: Al-Khwārizmī and annular solar eclipse
}

\author{
Hamid-Reza Giahi Yazdi
}

Published online: 15 July 2011

(C) Springer-Verlag 2011

\section{Erratum to: Arch. Hist. Exact Sci. DOI 10.1007/s00407-011-0080-7}

Unfortunately only after online first article publication some imperfections were noticed, the article text should had read the following:

At Footnote 22: al-Irānshahrī

At Footnote 27: Ibn ${ }^{\mathrm{c}} \mathrm{Ibr} \overline{1}$

Under Heading 2 Concluding remarks: For a long period of time, historians of astronomy have simply introduced al-Battānī (d. 317 A.H./929 A.D.) as the pioneer in Islamic astronomy (or even in the history of astronomy) who knew the possibility of annular solar eclipse. ${ }^{56}$

Communicated by George Saliba.

The online version of the original article can be found under doi:10.1007/s00407-011-0080-7.

H.-R. Giahi Yazdi $(\bowtie)$

History of Science Department, Encyclopaedia Islamica Foundation,

P.O. Box 14155-6195, Tehran, Iran

e-mail: hgiahi@gmail.com 